Research.

\title{
AN ANALYSIS OF THE CREDIT SERVICE EARNINGS UPON THE BALANCE OF BUSINESS REVENUES AT THE CREDITS AND SAVINGS BUSINESS UNIT OF KPRI IN SUKABUMI
}

\author{
Nani Pujiastuti \\ Department of Accounting, Polytechnic of Bina Budaya Cipta (BBC), Sukabumi, Indonesia \\ nanipujiastuti58@gmail.com (N.Pujiastuti)
}

\begin{abstract}
Received: September 28, 2018; Accepted: November 19, 2018; Published: December 31, 2018
To cite this article: Nani Pujiastuti. An Analysis of The Credit Service Earnings upon The Balance of Business Revenues at The Credits and Savings Business Unit of KPRI in Sukabumi, The Accounting Journal of BINANIAGA, Vol. 03, No. 02, December 2018, pp. 29-40.
\end{abstract}

\begin{abstract}
An analysis of the Credit Service Earnings upon Balance of Business Revenues at the Credits and Savings Business Unit (SPU) of KPRI in Sukabumi". This research has been done since the writer is interested in figuring out the problems about the earnings of credit services at KPRI in Sukabumi and the balance of business revenues (SHU) at KPRI in Sukabumi, as well as how to analyze the credit service earnings upon the balance of business revenues at the credits and savings business unit of KPRI in Sukabumi. However, this research is a quantitative study using a descriptive approach where the writer has been describing only the existing data using a qualitative description. Technique of data collection has applied field study research and library study. The result of the research has indicated that the earning of credit services at KPRI in Sukabumi has been increasing from year to year. The biggest increasing one was happened in 2009 which was Rp $846,979,876.00$ higher than the previous year, and the smallest one was happened in 2012 which was Rp 231,494,441.00 less than the previous year. Nevertheless the balance of business revenue has been increasing from 2009 to 2011 but it has decreased in 2012. The biggest increasing one was happened in 2009 which was $R p$ $89,261,608.00$ and it was decreased in 2012 which was $R p$ 18,352,811.00. The decreasing of this revenue was happened due to the total amount of business revenue had been received only from the credit units and other earnings. But, not any revenue of goods credit facilities had been received since there has not any transactions of goods selling been occured in 2012. Based on the analysis of the credit service earnings upon the balance of business revenues at KPRI in Sukabumi, it has indicated that the earnings of credit service has been relatively fluctuative each year. The contribution of the credit service earnings upon the balance of business revenue in 2008 was the biggest one which was $15.76 \%$ and the lowest one was in 2012 which was $1.79 \%$.
\end{abstract}

Key words: Credit, Saving, Service Earning, Business Revenue.

\section{INTRODUCTION}

\section{Background of The Problems}

A cooperation institution does not use profit terms to indicate the balance of the revenues at a certain period and the efforts to get the related earnings. This kind of balance is named a balance of business revenue (SHU). The balance of business 
revenue will be given to the members after being deducted from several business liabilities. The amount of the SHU is calculated based on the amount of the member's contribution and investment. Their contributions are defined according to their transaction that has been done with the cooperation unit at a certain period of time and the balance of the members capital is indicated on their primary savings and obligation one.

According to Rudianto's (2010:193) definition "the balance of business revenues at the current period is the balance between the earnings received at a certain period of time and the efforts given to get the related gross earnings which has not been allocated yet to other funds".

SHU has to be calculated in details to obtain the balance of business revenue received either from the transactions of the members or non-members. A part of the balance of business revenue will be returned to the members according to their contributions and the rest will be allocated to several funds belong to the cooperation unit as financial back-up.

The allocation of SHU for the Cooperation Association of Civils Servants of the Republic of Indonesia in Sukabumi (KPRI-PKS) has been done based on the official documents of the establishment of the cooperation and the statutes of changes stated, and it is allocated for the members, management, cooperation education, the development of the district area, social and cooperation's backup funds.

$\mathrm{SHU}$ of the cooperation is the cooperation revenues received within a booked-year deducted by cost, depreciation, and other liabilities including tax liability. The cooperation unit should have to satisfy the members as the owner of the business and the cooperation is obliged to obtain a profit or SHU which will be distributed to the members concerned at the year-end period. Therefore, the cooperation has to be able to allocate the financial resources efficiently and costs reducing to increase the profit or SHU in the future. Efficiency means the efforts of the cooperation to obtain the profit or SHU.

Referring to Rudianto's (2010:201) definition “Revenue or earnings is an increasing of the total assets owned by the cooperation unit which is not caused by the increasing of credit amount or the capital of the members". According to this definition, revenue is related to the increasing of the assets, cooperation liabilities and the additional capital investment from the members which is the primary savings and obligation savings. Based on the aforementioned description, it has been describing how the cooperation unit has increased its revenue.

The cooperation unit of the civils servants in Sukabumi is a cooperation unit dealing with savings and credits services as the main core of its business which has been doing its best to increase the revenue which is from savings and credit loans facilities.

In compliance with the aforementioned background, the writer has decided to analyze the related problems refers to the title of "An Analysis of Credits Service Earnings upon The Balance of Business Revenues at The Savings and Credits Loan (USP) at KPRI in Sukabumi".

\section{Problems Identification}

Based on the aforementioned background, the writer has tried to identify the following problems to be analyzed;

1. How is the earnings of credits service at the Cooperation association of the civil servants of the Republic of Indonesia in Sukabumi occured?

2. How is the balance of business revenue (SHU) of the savings and credit loans unit of the Cooperation association of the Civil Servants of Republic of Indonesia in Sukabumi (KPRI-PKS occured?

3. How has the analysis of the credit service earnings happened upon the balance of savings and credits business unit at the Cooperation Association of the Civils Servants of Republic Indonesia in Sukabumi (KPRI-PKS)?

Nani Pujiastuti. An Analysis of The Credit Service Earnings upon The Balance of Business Revenues at The Credits and Savings Business Unit of KPRI in Sukabumi 


\section{Objectives of The Research.}

The objectives of the research is to enrich the sciences of the accountancy economics, especially in the analysis of the credits service earnings upon the balance of business revenue (SHU) at the savings and credits unit of the Cooperation Association of the Civils Servants of the Republic Indonesia in Sukabumi (KPRI-PKS) as the basic of the science research at the accountancy department STIE PGRI in Sukabumi as to implement the knowledge obtained from the university in the real-life.

Referring to the aforementioned background and problems designs, the objectives of this research are as follows;

1. Finding out the earnings of the credits services at the Cooperation Association of the Civils Servants of the Republic Indonesia in Sukabumi (KPRI-PKS).

2. Finding out the balance of business revenue (SHU) of savings and credits unit(USP) at the Cooperation Association of The Civils Servants of the Republic Indonesia in Sukabumi (KPRI-PKS).

3. Finding out the analysis of credits services earnings upon the balance of business revenue at the Savings and Credits unit (SHU) of the Cooperation Association of the Civils Servants of the Republic Indonesia in Sukabumi (KPRI-PKS).

\section{Benefit of The Research}

This research is expected to provide more benefits to all the persons concerned, especially to;

\section{KPRI Sukabumi.}

This researh is expected to provide a good reference in line with the development of the Cooperation Association of the Civils Servants of the Republic of Indonesia in Sukabumi, specifically related to the analysis of the earningsof credit services and the balance of business revenue (SHU) at the savings and credits unit (SHU).

\section{Campus}

This research is expected to give more additional knowledge and can be a reference which is especially the study about the related problems studied in this research. Moreover, as a reference study for the students who are going to prepare a scientific research and the final study which is in line with the title of "An Analysis of the credit services earnings upon the balance business revenue (SHU) at the savings and credits unit (USP) at KPRI Sukabumi.

\section{The Researcher concerned}

This research is expected to enrich the perspective and knowledge in finance management especially related to the earnings of credits services upon the balance of busines revenues (SHU). However, it could be a comparative media between the theory obtained during the lecturing and its application at the company where the research will be done.

\section{Other Parties}

This research is also expected to be used as a reference either for the study of other next researchers which is relating to the earnings of the credits services upon the balance of business revenues (SHU).

\section{The Perspective Design}

A perception is an important thing in the financial report, because the management of the company is eager to know how the business has been performed accordingly and how much revenue has been obtained within a certain of accounting period of time which is approved and in compliance with the applicable principles. 
According to Eldon S. Hendriksen (in Marianus Sinaga, 1993:164) defined "A revenue is a monetary expression received from all the products of services being transfered by a company to the customers within a certain period of time". This definition has determined that a revenue is measured based on the total of the products or services provided to the customers or buyers (using a certain currency). Hence, it is an outflow of the value of the products of services which has been transfered to the customers.

Referring to Donals E. Kiesco and Jerry J. Weygandy (1986:164) "Revenue is an inflow of cash or other properties in exchange for goods sole or services rendered".

Some data are obtained from the result of the research indicating the total amount of the earnings of credits services that has been providing a contribution for the balance of business revenues (SHU). The more the revenue of credits and savings services has been obtained, the more profit will be for the company since the company can work on it as much as possible and it is not going to have a financial problem.

In connection with the aforementioned description, the earnings of the credits services have affected the balance of business revenues (SHU) at the savings and credits facilities (USP). It has happened at the Cooperation Association of the Civils Servants of the Republic of Indonesia in Sukabumi (KPRI-PKS). Refers to the data obtained from the financial report of 2008 to 2012, the revenue of the Cooperation Association the Civils Servants of the Republic of Indonesia in Sukabumi has been changed and given an impact to the balance of business revenues (SHU).

The aforementioned perception is as follows;

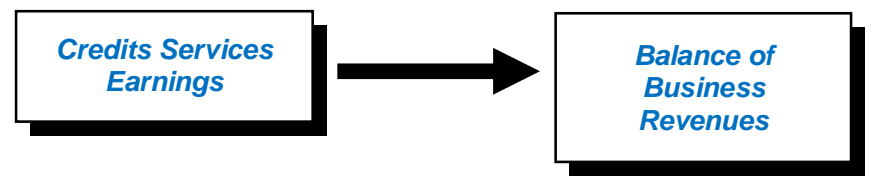

Figure 1

Perception Design

\section{Location and Time of The Research}

Getting the data and information required for this study, the writer has conducted a research at the Cooperation Association of the Civils Servants of the Republic of Indonesia in Sukabumi (KPRI-PKS) at Jalan Perpustakaan No.1 Sukabumi. And the time of the research had been taken in April 2012 to June 2012. The Schedule of the research is as follows;

\section{RESEARCH METHODOLOGY}

The Balance of Business Revenues (SHU) is the balance of the cooperation unit earnings obtained within a yearly booked period deducted by costs, depreciation and other liabilities of the related year.

Refers to chapter 45 article (1) ACTS No. 25/1992;

1. The Balance Revenue of the Cooperation Business is the cooperation unit revenues obtained within a yearly period deducted by costs, depreciation and other liabilities including tax liability at the related year.

2. SHU after being deducted by reserved funds will be distributed to the members according to the contribution of the members to the cooperation unit, and it is going to be used for the education of the cooperation unit and its requirements which is in compliance with the results of the Members Meeting.

3. The total amount of the reserved capital is determined in the Members Meeting.

Nani Pujiastuti. An Analysis of The Credit Service Earnings upon The Balance of Business Revenues at The Credits and Savings Business Unit of KPRI in Sukabumi 
4. The amount of the revenues to be shared to the members has been determined in the Members Meeting and in line with the statutes and rules of the Cooperation Association.

5. Every member will get a varied income due to their capital invested and the total of their transaction to define the Cooperation Association revenues.

6. The more the transactions (effort and capital) of the members given to the cooperation association, the bigger amount of the SHU will be received.

It can be concluded that the balance of business revenues is the revenue of the cooperation association received within a yearly booked record deducted by the costs, depreciation, other liabilities including Tax and Zakat that have to be paid at the related year.

The revenue is the main goals of the company to achieve. As a matter of fact, much revenue received by the company, it can be used for the operational activities for the next period of the year with a bigger scale than before. The revenue is a core of the feedback for the operational activities which is the start-up to measure the achievement of the company calculating the profit and loss of the company at a certain period of time.

Refers to Zaki Baridwan (1992:30)" Revenue is an in flow of the revenue or an increasing of other assets of the company or liabilities settlement (or both combination) within a periode of time which is receivable from products manufacturing or distribution, services distribution, or other activities as the business unit's operation". Based on the aforementioned description, it can be concluded that the revenue has been affecting the profit with the assumption that other costs are fixed considerately.

According to the aforementioned description, it explains that the total amount of the balance of business revenue has been affected by the total amount of the revenues, other costs, depreciation cost and tax liabilities of the cooperation unit.

The writer is going to do the research about the SHU and the revenue. The independent variable is the revenue and dependent variable is the balance of business revenue (SHU) which has been designed in the following research design:

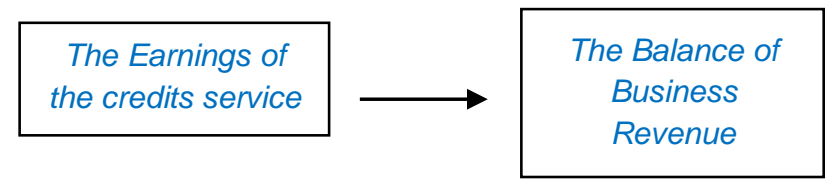

Figure 2

Research Design

\section{Research Design}

Research Design consists of:

1. Analyzing the earnings of the credits service and the balance of business revenue (SHU) of the credits and savings unit (USP) by collecting the financial statement of the company which is the Balance Statement for the period of 5 years $2008-2012$.

2. The research has applied an analysis unit which is the finance department of the Cooperation association of the civils servants of the Republic of Indonesia in Sukabumi.

The variables of this research are consisting of two variables, variable $(X)$ refers to the revenue variable and variable $(Y)$ refers to the variable of the balance of business revenue (SHU). In this part, the writer is going to describe the definition of the variables, dimensions, indicators, and measuring scale of the research which has been done at the Cooperation Association of the Civils Servants of the Republic of Indonesia in Sukabumi (KPRI-PKS).

Nani Pujiastuti. An Analysis of The Credit Service Earnings upon The Balance of Business Revenues at The Credits and Savings Business Unit of KPRI in Sukabumi 
Based on the aforementioned variables explanation, then the related operational variables can be seen on the following operational table:

Table 1

Operational Variables

\begin{tabular}{|c|c|c|c|c|}
\hline Variable & Definition & Dimension & Indicator & Scale \\
\hline $\begin{array}{l}\mathrm{X} \text { variable is } \\
\text { the Revenue. }\end{array}$ & $\begin{array}{l}\text { Revenue is an inflow or } \\
\text { assets increasing of a } \\
\text { business unit or } \\
\text { liabilities payment (or } \\
\text { both combination) in a } \\
\text { certain period refers to } \\
\text { the product } \\
\text { manufacturing and } \\
\text { distribution, service } \\
\text { distribution, or other } \\
\text { activities which are the } \\
\text { core activity of the } \\
\text { business, Zakie } \\
\text { Brodwin (2991:30) }\end{array}$ & $\begin{array}{l}\text { 1. Business } \\
\text { revenue } \\
\text { 2. } \begin{array}{l}\text { Non- } \\
\text { Business } \\
\text { revenue }\end{array}\end{array}$ & $\begin{array}{l}\text { 1. Services } \\
\text { earnings } \\
\text { 2. Goods revenue } \\
\text { 3. Interest revenue } \\
\text { 4. Account } \\
\text { receivable } \\
\text { 5. Loans }\end{array}$ & Ratio \\
\hline $\begin{array}{l}\mathrm{Y} \text { variable is } \\
\text { the balance of } \\
\text { business } \\
\text { revenue (SHU }\end{array}$ & $\begin{array}{l}\text { Balance of Business } \\
\text { revenue (SHU) is the } \\
\text { revenue received at a } \\
\text { certain period } \\
\text { deducted by } \\
\text { depreciation and other } \\
\text { liabilities at the related } \\
\text { year-book (Somerson } \\
2005: 208)\end{array}$ & $\begin{array}{ll}\text { 1. Yearly } \\
\text { revenue } \\
\text { 2. Yearly } \\
\text { Liability }\end{array}$ & $\begin{array}{l}\text { 1. Balance of the } \\
\text { revenue and } \\
\text { liability } \\
\text { 2. Selling of the } \\
\text { goods } \\
\text { 3. Selling of the } \\
\text { services } \\
\text { 4. Operational } \\
\text { Costs }\end{array}$ & Ratio \\
\hline
\end{tabular}

\section{RESEARCH INSTRUMENT}

\section{Date collection Tools}

1. Interview, is the data collection by offering direct questions to the staffs and the employees regarding the data required.

2. Observation, is a direct field observation upon the objects to study, including the data of documentation and notes of the company.

The specific data obtained from the Cooperation Association of the Civils Servants of the Republic of Indonesia in Sukabumi (KPRI-PKS)

Collecting the data based on:

1. The Financial Report which is the financial list prepared at the end of the period.

2. The Library Review which is the data collection technique by looking for the information required at the Library.

3. The Documentation Study which is the data collection to record the data obtained from the research objects.

4. Data collected have to be analyzed to indicate how the analysis of the credits service earnings has affected the balance of business revenue (SHU)

\section{Procedure of Data Research}

Obtaining the accurate data required, the writer has applied some procedure to collect the data required, as follows:

1. Analyzing the data obtained from the company.

Nani Pujiastuti. An Analysis of The Credit Service Earnings upon The Balance of Business Revenues at The Credits and Savings Business Unit of KPRI in Sukabumi 
2. Performing a direct field observation against the research objects including the data collection which is from the company's documentation and records.

3. Conducting a verbal interview directly to the employees or the management related to this research and recording the result.

\section{Data Analysis Technique}

This research has applied a horizontal analysis. It is an analysis comparing some financial reporting for some periode of time or some certain of time to indicate the financial improvement.

Refers to S. Munawir in his book of An Analysis of the Financial Reporting (2004:36)"A comparison analysis of financial reports is an analysis method and technique by comparing some financial reports for two periode of time or more, by indicating:

1. Absolute data or the total amount in rupiah currency.

2. Increasing or decreasing the total amount in rupiah

3. Increasing or decreasing in percentage.

4. Comparison is determined by ratio.

5. Percentage of the total.

Using this analysis method is expected to identify some changes (increasing or decreasing) happened within some period of time, and some changes should have required for further research.

\section{RESULT OF THE RESEARH AND DESCRIPTION}

\section{Research Description}

\section{The Earnings of The Credits Service at KPRI-PKS}

Refers to C.Rolin Niswonger and Carl S. Waren (in Hyginus Ruswianarto, 1993: 57) 'Revenue is gross increasing of the owners' capital investment obtained from the selling of the trading goods, service given to the clients or customers, rented assets, cash loans, and all the business activities and the professional activities to obtain the revenue".

The earnings of the service described in this writing is the revenue of credits service in the quantitative concept. The earnings of the credits service of the Cooperation Association of the Civils Servants of the Republic of Indonesia in Sukabumi (KPRI-PKS) year of 2008 to 2012 can be identified on the table here below:

Table 2

The Earnings of the Credits Service of KPRI-PKS

\begin{tabular}{|c|c|c|}
\hline $\begin{array}{c}\text { Periode of } \\
\text { Time }\end{array}$ & $\begin{array}{c}\text { Total Amount of The Earnings of } \\
\text { The Credits Service }\end{array}$ & $\begin{array}{c}\text { Total Amount of The Increasing / } \\
\text { Decreasing of The Earnings of } \\
\text { Credits Service }\end{array}$ \\
\hline 2008 & $\operatorname{Rp} 930.064 .835,00$ & $\operatorname{Rp~} 846.979 .867,00$ \\
\hline 2009 & $\operatorname{RP} 1.777 .044 .702,00$ & $\operatorname{Rp~} 622.837 .521,00$ \\
\hline 2010 & $\operatorname{Rp} 2.399 .882 .223,00$ & $\operatorname{Rp~} 400.056 .127,00$ \\
\hline 2011 & $\operatorname{RP} 2.799 .938 .350,00$ & $\operatorname{Rp~} 231.494 .441,00$ \\
\hline 2012 & $\operatorname{Rp} 3.031 .432 .791,00$ & \\
\hline
\end{tabular}

Refers to the aforementioned table, it has indicated that the earnings of credits service of KPRI-PKS within the year of $2008-2012$ had been fluctuated. This company received the highest revenue in 2012 which was $R p 3,031,432,791.00$ and the lowest one was in 2008 which wasRp 930,064,835.00. Overall the revenue of credits service of KPRI-PKS had been increased significantly since people have been fully aware of the benefit joining the Cooperation Association of the Civils Servants of the Republic Indonesia in Sukabumi (KPRI-PKS).

Nani Pujiastuti. An Analysis of The Credit Service Earnings upon The Balance of Business Revenues at The Credits and Savings Business Unit of KPRI in Sukabumi 
The aforementioned table has indicated also that the earnings of credits service of KPRI-PKS had mostly increased in 2009 amounting to Rp 846,979,867.00 compared to the revenue in 2008.

In order to ease the understanding and analyzing the increasing and decreasing of the earnings of credits service of KPRI-PKS during 2008 - 2012, it can be identified on the undermentioned graph:

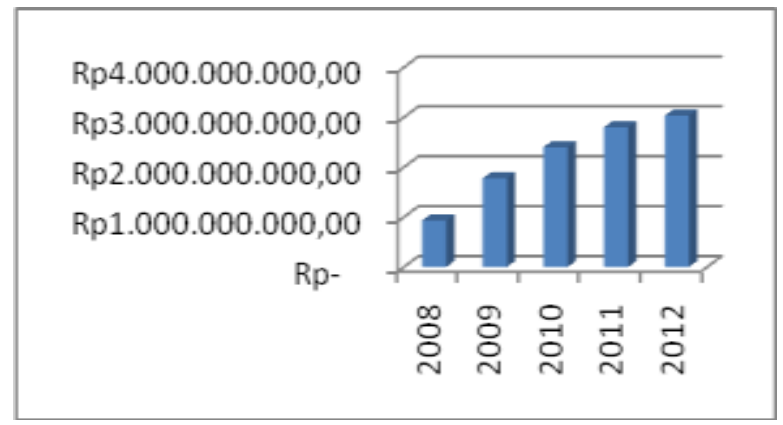

Figure 3

Graph changing of the Earnings of Credits Service of KPRI-PKS in 2008 - 2012

\section{Balance of The Business Revenue (SHU) KPRI-PKS}

To analyze the balance of the Business Revenue of KPRI-PKS, the writer has picked the data of the financial statement which is specifically the data of the calculation of the balance of business revenue (SHU) KPRI-PKS during the year of $2008-2012$. The data are as follows:

Table 3

Balance of the Business Revenue of KPRI-PKS

\begin{tabular}{|c|c|c|}
\hline Periode & $\begin{array}{l}\text { Total Amount of The } \\
\text { Balance of Business } \\
\text { Revenue (SHU) }\end{array}$ & $\begin{array}{l}\text { Total Amount of The } \\
\text { Increasing / Decreasing } \\
\text { of The Balance of } \\
\text { Business Revenue } \\
\text { (SHU) }\end{array}$ \\
\hline 2008 & Rp $146.650 .914,00$ & \\
\hline 2009 & RP $\quad 235.912 .522,00$ & Rp $\quad 89.261 .608,00$ \\
\hline 2010 & Rp $\quad 264.526 .579,00$ & Rp $\quad 28.614 .057,00$ \\
\hline 2011 & RP $\quad 272.896 .561,00$ & $8.396 .982,00$ \\
\hline 2012 & Rp $\quad 254.543 .750,00$ & $(\operatorname{Rp} 18.352 .811,00)$ \\
\hline
\end{tabular}

The aforementioned table has indicated that the balance of business revenue (SHU) of KPRI-PKS in 2008 up to 2012 had been fluctuated. This company had gotten the biggest total amount of the balance of business revenue in 2011 amounting to $\mathrm{Rp}$ $272,896,561.00$ and the lowest one was in 2008 amounting to Rp 146,650,914.00. Nevertheless, the balance of business revenue had been decreased to Rp 18,352,811.00 in 2012 comparing to the year of 2011.

The aforementioned table has indicated also that the balance of business revenue (SHU) of KPRI-PKS had mostly increased in 2009 amounting to Rp 89,261,608.00 comparing to the year of 2008.

Nani Pujiastuti. An Analysis of The Credit Service Earnings upon The Balance of Business Revenues at The Credits and Savings Business Unit of KPRI in Sukabumi 
In order to ease the understanding and analyzing the increasing and decreasing of the balance of business revenue (SHU) of KPRI-PKS during the year of $2008-2012$, the following graphs has explained it.

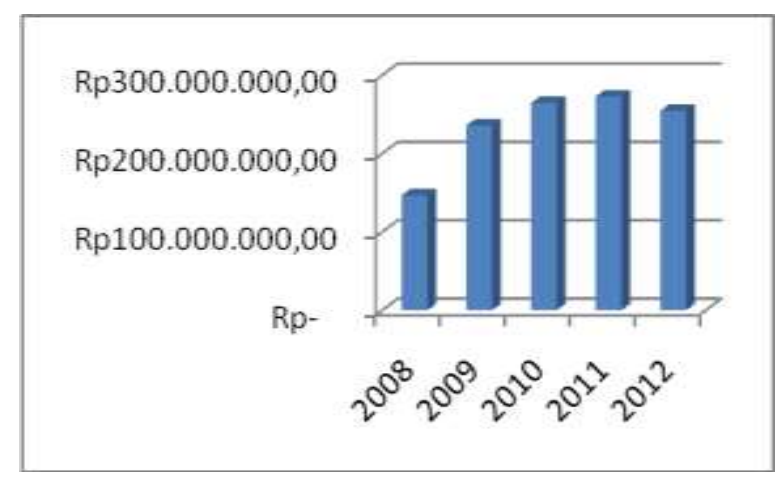

Figure 4

Graph changing of the balance of business revenue (SHU) of KPRI-PKS Year $2008-2012$

\section{The Analysis of The Earnings of The Credits Service upon The Balance of Business Revenue (SHU) at The Savings and Credits Unit (USP) KPRI-PKS}

An Analysis of the Earnings of Credits Service upon the Balance of Business Revenue (SHU) at the Savings and Credits Unit (USP) at the Cooperation Association of the Civils Servants of the Republic Indonesia in Sukabumi (KPRI-PKS) has been obtained by comparing the report of the calculation of the balance of business revenue within the related year with the previous one. This analysis has been done based on the report of the calculation of the balance of business revenue of KPRI-PKS during 2008 2012. The result of the analysis is as the following:

Table 4

The Earnings of Credit Service and The Balance of Business Revenue (SHU) KPRIPKS

\begin{tabular}{|c|c|c|c|c|c|c|}
\hline \multirow[b]{2}{*}{ Periode } & \multirow{2}{*}{$\begin{array}{l}\text { Earnings of } \\
\text { Credits } \\
\text { Service }\end{array}$} & \multirow{2}{*}{$\begin{array}{c}\text { Balance of } \\
\text { the } \\
\text { Business } \\
\text { Revenue }\end{array}$} & \multicolumn{2}{|c|}{ Increasing / Decreasing } & \multicolumn{2}{|c|}{$\%$} \\
\hline & & & Revenue & $\begin{array}{c}\text { Balance of the } \\
\text { Business } \\
\text { Revenue } \\
\end{array}$ & $\begin{array}{l}\text { Income } \\
\text { (Rp) }\end{array}$ & $\begin{array}{l}\text { SHU } \\
\text { (Rp) }\end{array}$ \\
\hline 2008 & 930.064 .835 & 146.650 .914 & & & & \\
\hline 2009 & 1.777 .044 .702 & 35.912 .522 & 846.979 .867 & 89.261 .608 & 91,07 & 60,87 \\
\hline 2010 & 2.399 .882 .223 & 64.526 .579 & 622.837 .521 & 28.614 .057 & 35,05 & 12,13 \\
\hline 2011 & 2.799 .938 .350 & 72.896 .561 & 400.056 .127 & 8.396 .982 & 16,67 & 3,17 \\
\hline 2012 & 3.031 .432 .791 & 54.543 .750 & 231.494 .441 & $(18.352 .811)$ & 8,27 & $(6,73)$ \\
\hline
\end{tabular}

Based on the aforementioned table, it has indicated that the total amount of the earnings of credits service had been fluctuated during 2008-2012. The most increasing had happened in 2009 which was $91.07 \%$ comparing to the year of 2011 . However, the revenue of the balance of business revenue had been increasing during 2008-2011, but it had been decreased in 2012 amounting to $\mathrm{Rp} 18,352,811.00$ or $6,73 \%$ against the year of 2011. Nevertheless, the most increasing of the balance of business revenue had happened in 2009 which was $60.87 \%$.

Nani Pujiastuti. An Analysis of The Credit Service Earnings upon The Balance of Business Revenues at The Credits and Savings Business Unit of KPRI in Sukabumi 
Anwar, $Y$ and Murwaningsari, E (2016), revealed that credit risk as measured by non-performing loan (NPL) has a significant influence on profitability in the banking industry listed on the Indonesia Stock Exchange (IDX). In order to identify the contribution of the earnings of the credits service upon the balance of business revenue, the following table has indicated the ratio between the earnings of credits service and the balance of business revenue.

Table 5

Ratio of the Revenue of Credits Service and the Balance of Business Revenue (SHU) KPRI-PKS

\begin{tabular}{|c|r|r|r|}
\hline Periode & $\begin{array}{c}\text { Revenue of The } \\
\text { Credits Service } \\
\text { (Rp) }\end{array}$ & $\begin{array}{c}\text { Balance of } \\
\text { The Business } \\
\text { Revenue (Rp) }\end{array}$ & $\begin{array}{c}\text { Ratio } \\
(\%)\end{array}$ \\
\hline 2008 & 930.064 .835 & 146.650 .914 & 15,76 \\
\hline 2009 & 1.777 .044 .702 & 35.912 .522 & 2,02 \\
\hline 2010 & 2.399 .882 .223 & 64.526 .579 & 2,68 \\
\hline 2011 & 2.799 .938 .350 & 72.896 .561 & 2,60 \\
\hline 2012 & 3.031 .432 .791 & 54.543 .750 & 1,79 \\
\hline
\end{tabular}

Based on the aforementioned table, it has indicated that in 2008 the earnings of the credits service has given a contribution of $15.76 \%$ upon the balance of the business revenue. In 2009 the earnings of the credits service had given a contribution of $2.02 \%$ upon the balance of business revenue. In 2010 the earnings of the credits service had given a contribution of $2.68 \%$ upon the balance of business revenue. In 2011 the earnings of the credits service had provided a contribution of $2.60 \%$ upon the balance of the business revenue. Nevertheless, in 2012 the revenue of the credits service had provided a contribution of $1.79 \%$ upon the balance of the business revenue. However, the biggest contribution of the earning of credits service upon the balance of business revenue was $15.76 \%$ in 2008 and the lowest one was $1.79 \%$ in 2012 .

\section{REFERENCES}

Anwar, Y and Murwaningsari, E. (2016). The Effect of Credit Risk and Capital Adequacy Ratio Upon Return on Asset (A Case Study at Banking Listed in Indonesia Stock Exchange), The Accounting Journal of Binaniaga. 2 (2), pp 23-38.

Arikunto, S. (2002). Research Procedure, a Practical Approach, PT. Rineka Cipta, Jakarta.

Baridwan, Z. (1992), Intermediate Accounting, Seventh Edition, BPFE, Yogyakarta.

Dantes, N. (2012). Research Method, Andi, Yogyakarta.

Djarwanto Ps, (2001). The Principles of the Analysis of the Financial Report, BPFEYogyakarta.

Eldon S. H. (1993). Accounting Theory, Erlangga, Jakarta.

Harahap, SS. (2004). Accountancy of Fixed Assets, third edition, Third edition, PT. Raja Grafindo, Jakarta.

Harahap, SS. (2011), Accountancy Theory, revised edition, Raja Grafindo Persada, Jakarta.

Nani Pujiastuti. An Analysis of The Credit Service Earnings upon The Balance of Business Revenues at The Credits and Savings Business Unit of KPRI in Sukabumi 
Horngren, C. (1997), Accountancy in Indonesia Akuntansi di Indonesia, Salemba Empat, Jakarta.

Indonesian Accountants Association, (2008), Standard of Finance Accountancy, Salemba Empat, Jakarta.

Indonesian Accountants Association. (2007). Standard of Finance Accountancy. Edition of 2007. Salemba Empat. Jakarta.

Jumingan. (2009). Analysis of the Financial Report, Bumi Aksara, Jakarta.

Jusup, AH. (2006), Basic of the Accountancy Book, edition $6^{\text {th }}$, Aditya Media, Yogyakarta.

Kasmir. (2010). Analysis of the Financial Report. First Edition. Jakarta, Rajawali Pers.

Kusnadi. (2000), Intermediate Accounting, Unibraw, Malang.

Mardi, (2011). System of an accountancy information, Ghalia Indonesia. Ciawi Bogor.

Meigs, Walter B. and Robert F. Meigs. (1970), Financial Accounting, 4th ed. McGraw-Hill, p.1. (old edition).

Mulyadi. (2009). Cost Accountancy, edition $5^{\text {th }}$. STIM YKPN, Yogyakarta.

Munawir. (2004), Analysis of the Financial Report Fourth Edition, Liberty, Yogyakarta.

Niswonger, CR. Warren, CS and Fees, PE. (1993), Accounting Principle, Sixteen Edition, Jakarta.

Priatna, RB. (2010). Finance Accountancy 1, Ghalia Indonesia, Bogor.

Rudianto (2012), Introduction to Accounting, Erlangga, Yogyakarta.

Rudianto. (2010). Accountancy of the Cooperation Association Second edition, Erlangga, Jakarta.

Stice and Skousen. 2009. Intermediate Accounting, Sixth Edition, Book 1, Salemba Empat, Jakarta.

Sugiyono. (2009), Administration Research Method, Afabeta, Bandung.

The Regulations of the Cooperation Association. (2012). Fokusmedia, Bandung.

Nani Pujiastuti. An Analysis of The Credit Service Earnings upon The Balance of Business Revenues at The Credits and Savings Business Unit of KPRI in Sukabumi 
The Accounting Journal of BINANIAGA Vol. 03, No. 02, December 2018

PISSN: $2527-4309$

EISSN: $2580-1481$

This page intentionally be emptied.

Nani Pujiastuti. An Analysis of The Credit Service Earnings upon The Balance of Business Revenues at The Credits and Savings Business Unit of KPRI in Sukabumi 